\title{
Papillary renal cell carcinoma and collecting duct carcinoma combination. A case report and review of synchronous renal cell carcinoma subtypes in the same kidney
}

Deniz Arık ${ }^{1}$, Mustafa Fuat Açıkalın¹, Cavit Can²

\author{
${ }^{1}$ Department of Pathology, Faculty of Medicine, Eskisehir Osmangazi University, \\ Eskişehir, Turkey \\ ${ }^{2}$ Department of Urology, Faculty of Medicine, Eskisehir Osmangazi University, \\ Eskişehir, Turkey
}

Submitted: 24 January 2014

Accepted: 18 February 2014

Arch Med Sci 2015; 11, 3: 686-690

DOI: $10.5114 /$ aoms.2015.52378

Copyright $\odot 2015$ Termedia \& Banach

Collecting duct carcinoma (CDC), also known as Bellini duct carcinoma, is a rare neoplasm comprising less than $1 \%$ of renal epithelial tumors [1]. Collecting duct carcinoma is an aggressive neoplasm and is thought to arise from the collecting ducts of renal medulla [2]. Papillary renal cell carcinoma (PRCC) comprises $10 \%$ of renal cell carcinomas (RCC) and has distinct cytogenetic and molecular features [3].

Concurrent primary neoplasms of the kidney have been rarely reported in the literature as an association of RCC and transitional cell carcinoma (TCC) or oncocytoma [4-6]. But coexistence of the RCC subtypes in the same kidney is exceptional.

To the best of our knowledge, 20 cases have been reported to date as synchronous RCC subtypes in the same kidney [7-21]. Among them there have been only two cases of synchronous CDC and PRCC. In these cases, the tumors were usually seen as separate masses. In contrast, in some reports tumor components were seen as a single mass or "tumor in tumor" or with obvious histological transition [10, 12, 13, 15, 16].

Here we present the third case of CDC and PRCC association and the first one of this association as a "tumor-in-tumor" morphology.

A 42-year-old man initially presented with flank pain and hematuria. His personal or family histories were not contributory. In ultrasonography, soft tissue density was detected at the lower pole of the right kidney. An abdominal computed tomographic scan demonstrated a $38 \mathrm{~mm}$ cystic lesion and $35 \mathrm{~mm}$ mass with equal density in the renal cortex. A right radical nephrectomy with lymph node dissection was performed. Macroscopic examination showed a $10 \mathrm{~cm}$, solid, gray-white mass containing a $3.5 \mathrm{~cm}$ cystic area with papillary features in the renal parenchyma extending to the pelvis. Microscopically, the solid part of the mass revealed infiltrative tubuloglandular formations in a desmoplastic stroma. Tumor cells had large hyperchromatic and pleomorphic nuclei and relatively scant cytoplasm. The cystic part of the tumor showed entirely different histology consisting of papillary structures lined with columnar cells having coarse vesicular nuclei, prominent nucleoli and large eosinophilic cytoplasm. Dysplastic features were seen in the epithelium of the distal collecting ducts too. The tumor invaded the renal capsule and extended into the perirenal fat. Gerota's fascia, renal vein, ureter, and adrenal gland were free of

\author{
Corresponding author: \\ Deniz Arık \\ Department of Pathology \\ Faculty of Medicine \\ Eskisehir Osmangazi \\ University \\ 26480 Eskişehir, Turkey \\ Phone: +902222392979 \\ E-mail: denarik@hotmail.com
}


tumor. In the perirenal fat, four metastatic lymph nodes were detected. At the renal hilus, perineural invasion and tumor cell emboli were seen. In the perirenal fat, 7 lymph nodes were detected and 4 of them showed CDC component involvement. Lymph node dissection material from the right hilar, paracaval and right common iliac region revealed 13 lymph nodes with reactive hyperplasia. The adrenal gland was intact.

Immunohistochemistry showed different features in the two components. The solid component showed reactivity with CK-AE1 and CK19. Histochemically the mucicarmine and alcian blue stains were negative. At the cystic component, the tumor cells were focally positive for 34BE12 but not for CK-AE1 and CK19. Uroplakin, AMACR, CK7 and CD10 were negative for both tumor components (Figures 1-6).

The solid component was diagnosed as CDC with nodal metastasis, renal capsular and pelvic invasion. The cystic component was diagnosed as type 2 PRCC.

At this time no distant metastasis was detected by abdominal or thoracic computed tomographic scan. After 18 months, a millimetric hypodense nodule in the liver and a $13 \mathrm{~mm}$ lymph node in the upper paraaortic region were observed and immunotherapy was planned. After 3 months multiple metastatic nodules were detected in the liver, retrocrural, paraaortic and paratracheal regions, and vertebral bones. External radiotherapy to the vertebral region was planned. After 30 months multiple bone, liver, upper and lower paraaortic metastatic nodules were in progression.

Synchronous tumors in the same kidney is a rare occurrence. The RCC cases associated with angiomyolipoma, oncocytoma and TCC were presented as a small series in the literature [4-6]. However, combination of the subtypes of RCC (clear cell, chromophobe, papillary, collecting duct) in the same kidney is very rare. To the best of our knowledge, only 20 cases with different RCC subtypes in the same kidney have been reported (Table I). There were only two previously presented cases of PRCC with CDC in the literature [9, 14]. In one of these cases, separate masses both were located at the upper pole of the kidney. The PRCC was $2.5 \mathrm{~cm}$ and the CDC was $1.5 \mathrm{~cm}$ in diameter. The PRCC was evaluated as Fuhrman grade 2, while the CDC was low-grade [9]. In the other case, the CDC was $5.3 \mathrm{~cm}$ in diameter and located in the medullary region. The PRCC was located in the upper pole as a $0.5 \mathrm{~cm}$ mass. Our case is the third in the literature showing synchronous PRCC and CDC. However, our case is different from the others due to its "tumor-in-tumor" morphology. The PRCC was a $3.5 \mathrm{~cm}$ cystic mass located centrally in the $10 \mathrm{~cm}$ solid CDC. The tumor with papillary structures extending into the cystic space consistent with type
2 PRCC was easily recognizable. The CDC component was characterized by infiltrative small tubuloglandular structures lined with highly atypical cells in a desmoplastic stroma. These two different morphologies were clearly identifiable by light microscopy and immunohistochemical studies.

Similar to our case, 5 of the 20 synchronous tumors were not entirely separate masses. Cho et al. [12] reported a case with two different clonal expansions in one nodule, of unclassified RCC and CDC as nodule-in-nodule morphology with different karyotypic alterations and immunohistochemical results. Two cases of the combination of chromophobe renal cell carcinoma (CRCC) and CDC in the same kidney with histologic transition have been presented in the literature $[10,15]$. In the case reported by Kawano et al. [15] the most predominant histological component was the CRCC. The chromophobe cells also showed dedifferentiation. Besides this component, the CDC component was also noted, and the CRCC and CDC elements showed obvious transition to each other. The authors considered that their case was monoclonal in origin because of obvious histologic transition with CDC and chromophobe RCC elements. Gong et al. [10] reported that the CRCC component showed both CDC differentiation and sarcomatoid dedifferentiation, and concluded that the tumor was monoclonal because in metastatic focuses all three elements were seen [10]. In another case, the tumor exhibited varied cellularity with diverse architectural patterns, including solid sheets, nests, tubules, papillary formations, cords or trabeculae, and infiltrating neoplastic cells [13]. The tumor displayed intimate intermingling of histologic patterns described collectively in tumors of distal nephron derivation. There were architectural and cytologic features of oncocytoma, CRCC, and CDC, as well as sarcomatoid dedifferentiation with different karyotypic abnormalities. The authors concluded that the failure of special stains to separate one morphologic area from the other in the tumor suggests that this is a solitary, noncollision neoplasm demonstrating diverse (but closely related) morphologic differentiation of distal nephron derivation. The authors added that the karyotype of the tumor is most supportive of CRCC, but also shows the chromosomal abnormalities seen in oncocytomas and CDC. This tumor demonstrates, as is generally accepted, the ontogenetic proximity of oncocytoma, CRCC, and CDC. Roehrl et al. [16] reported another unique case of RCC that exhibited the features of both chromophobe and papillary carcinoma within the same tumor [16]. By light microscopy the two admixed tumor types could be readily distinguished from each other. Based on surface area estimates of representative tissue sections, approximately 


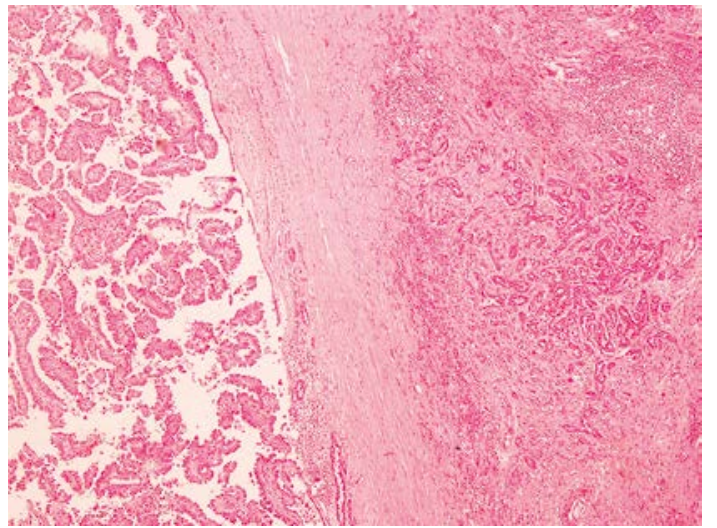

Figure 1. Papillary renal cell carcinoma (on the left) and collecting duct carcinoma (on the right) $(\mathrm{H}+\mathrm{E}, 40 \mathrm{x})$

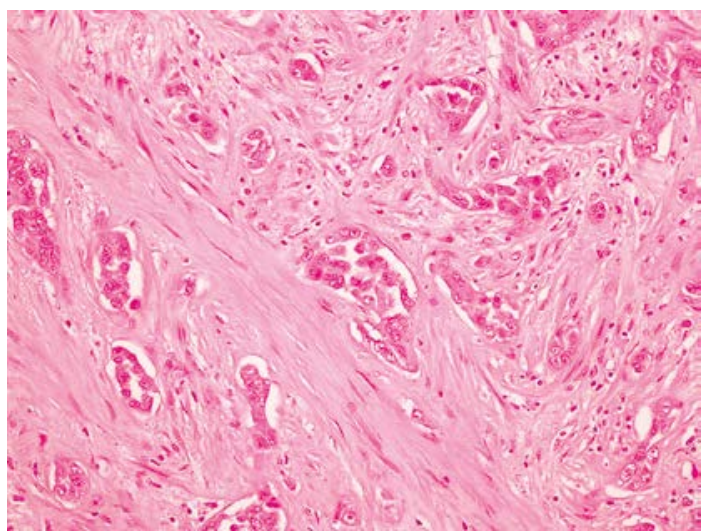

Figure 3. Infiltrative tubuloglandular formations in a desmoplastic stroma (H + E, 200x)

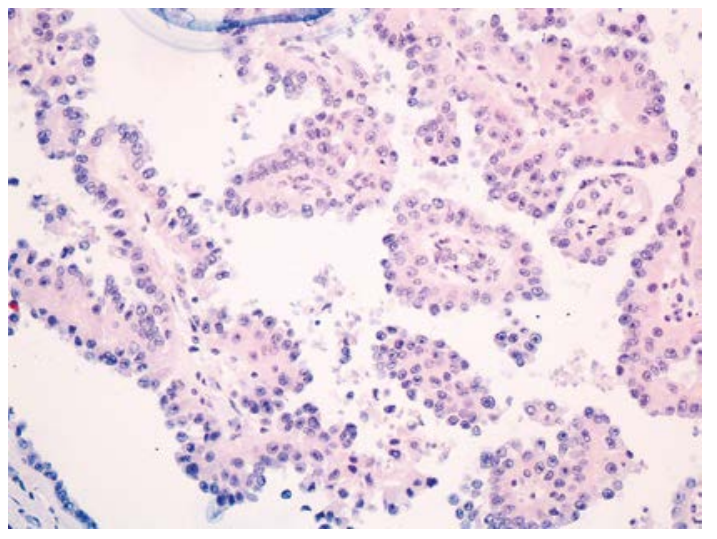

Figure 5. Papillary renal cell carcinoma component is negative with cytokeratin 19 (CK19, 200x)

$70 \%$ of the tumor was composed of chromophobe and $30 \%$ of papillary carcinoma. Immunohistochemical, electron microscopic and cytogenetic analysis of the tumor revealed distinct patterns too. According to the authors it was conceivable that their particular RCC may have arisen from a pluripotent cancer stem cell that was capable of recapitulating both proximal and distal nephron histogenesis, either by acquiring dichotomous ad-

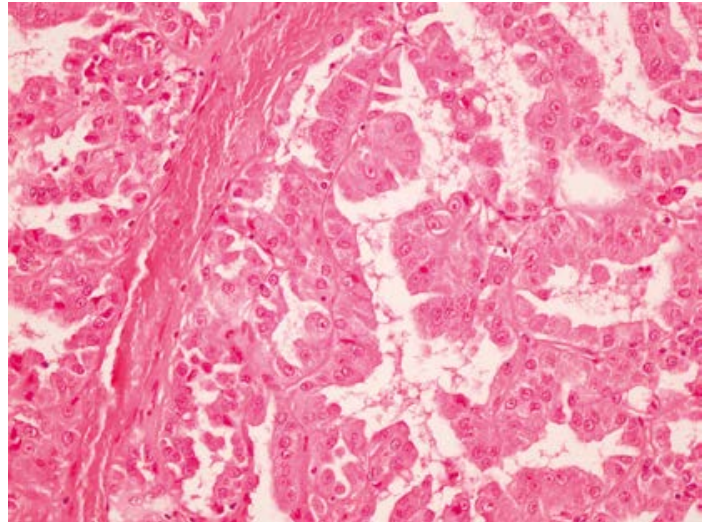

Figure 2. Papillary structures lined with columnar cells having coarse vesicular nuclei, prominent nucleoli and large eosinophilic cytoplasm (H + E, 200x)

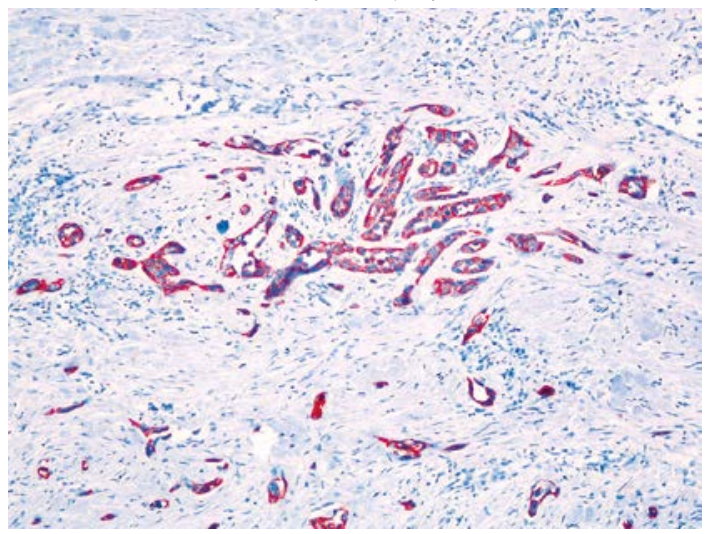

Figure 4. Collecting duct carcinoma component is positive with low molecular weight keratin $(A+E 1,100 x)$

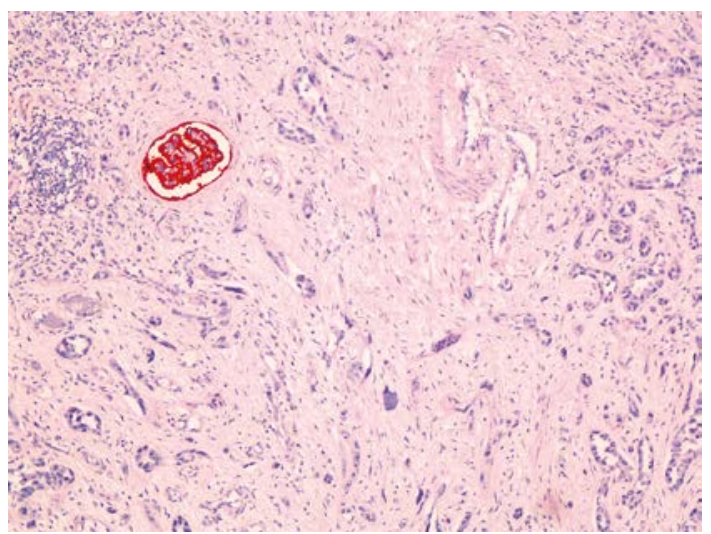

Figure 6. Collecting duct carcinoma component is positive with $C D 10$. On the upper left renal glomerulus seems to be positive (CD10, 100x)

ditional genetic alterations along the way of the two different morphogenic pathways (chromophobe vs. papillary) or by undergoing microenvironment-specific differentiation within the tumor.

Tumors that are separate masses in the same kidney are considered as synchronous tumors. If the tumors with different morphology are seen as a single mass or with histologic transition in the kidney, their pathogenesis should be peculiar. Re- 
Table I. Documented cases of synchronous RCC subtypes in the same kidney

\begin{tabular}{|c|c|c|c|c|c|}
\hline Study & $\begin{array}{l}\text { Age/ } \\
\text { sex }\end{array}$ & RCC subtype & Location & $\begin{array}{l}\text { Dimension } \\
{[\mathrm{cm}]}\end{array}$ & With \\
\hline \multirow{4}{*}{$\begin{array}{l}\text { Renshaw } \\
\text { et al. }\end{array}$} & \multirow[t]{2}{*}{$70 / \mathrm{F}$} & Papillary & NS & 3 & \multirow{2}{*}{$\begin{array}{l}\text { Radiologic evidence } \\
\text { of lung metastases }\end{array}$} \\
\hline & & Chromophobe & NS & 3 & \\
\hline & \multirow[t]{2}{*}{$62 / M$} & Papillary & NS & 4 & \multirow{2}{*}{$\begin{array}{l}\text { Radiologic evidence } \\
\text { of lung metastases }\end{array}$} \\
\hline & & Chromophobe & NS & 5.5 & \\
\hline \multirow{2}{*}{$\begin{array}{l}\text { Auget } \\
\text { et al. }\end{array}$} & \multirow[t]{2}{*}{$73 / M$} & Clear cell & Right upper pole & 1.3 & \\
\hline & & Collecting duct & Right lower pole & 6 & \\
\hline \multirow{2}{*}{$\begin{array}{l}\text { Daniel } \\
\text { et al. }\end{array}$} & \multirow[t]{2}{*}{$75 / M$} & Papillary & Right upper pole & 2.5 & \\
\hline & & Collecting duct (low grade) & Right upper pole & 1.5 & \\
\hline \multirow{2}{*}{$\begin{array}{l}\text { Gong } \\
\text { et al.* }\end{array}$} & \multirow[t]{2}{*}{$72 / M$} & Chromophobe & \multirow[t]{2}{*}{ Left lower pole } & \multirow[t]{2}{*}{ NS } & \multirow{2}{*}{$\begin{array}{l}\text { Transition with } \\
\text { sarcomatoid component }\end{array}$} \\
\hline & & Collecting duct & & & \\
\hline \multirow{2}{*}{$\begin{array}{l}\text { Jun } \\
\text { et al. }\end{array}$} & \multirow[t]{2}{*}{$62 / M$} & Chromophobe & Lower pole & 1.7 & \multirow{2}{*}{$\begin{array}{c}\text { Epithelioid } \\
\text { angiomyolipoma }\end{array}$} \\
\hline & & Clear cell & Lower pole & 0.6 & \\
\hline \multirow{2}{*}{$\begin{array}{l}\text { Cho } \\
\text { et al.* }\end{array}$} & \multirow[t]{2}{*}{$24 / M$} & Clear cell (unclassified) & Left inner nodule & 1.5 & \multirow{2}{*}{$\begin{array}{l}\text { Nodule-in-nodule } \\
\text { pattern }\end{array}$} \\
\hline & & Collecting duct & Left outer nodule & 14 & \\
\hline \multirow{2}{*}{$\begin{array}{l}\text { Lindgren } \\
\text { et al.* }\end{array}$} & \multirow[t]{2}{*}{$47 / M$} & Chromophobe & \multirow[t]{2}{*}{ Right lower pole } & \multirow{2}{*}{$\begin{array}{c}8.5 \mathrm{~cm} \text { as } \\
\text { a single } \\
\text { mass }\end{array}$} & \multirow{2}{*}{$\begin{array}{c}\text { Oncocytoma } \\
\text { and sarcomatoid } \\
\text { differentiation }\end{array}$} \\
\hline & & Collecting duct & & & \\
\hline Matei & $70 / M$ & Papillary & Left upper pole & 0.5 & \\
\hline et al. & & Collecting duct & Left medulla & 5.3 & \\
\hline Kawano & $64 / F$ & Chromophobe & Left middle to the lower & 4.3 & Obvious transition \\
\hline et al.* & & Collecting duct & portions & & $\begin{array}{l}\text { to each other with } \\
\text { dedifferentiation }\end{array}$ \\
\hline Roehrl & $65 / M$ & Papillary & Left superior pole & $5.4 \mathrm{~cm}$ as & \\
\hline et al.* & & Chromophobe & & $\begin{array}{l}\text { a single } \\
\text { mass }\end{array}$ & \\
\hline Tyritzis & $57 / M$ & Chromophobe & Lower pole & 12.5 & $0.2 \mathrm{~cm}$ subcapsular \\
\hline et al. & & Papillary & Upper pole & 5 & $\begin{array}{c}\text { tubulopapillary } \\
\text { adenoma }\end{array}$ \\
\hline Tsai et & $57 / F$ & Clear cell & NS & NS & TCC of renal pelvis and \\
\hline & & Collecting duct & & & \\
\hline Capaccio & NS & Papillary & Left upper pole & 6 & \\
\hline et al. & & Clear cell & Left lower pole & 1 & \\
\hline & NS & Papillary & Left lower pole & 4 & \\
\hline & & Clear cell & Left lower pole & 3 & \\
\hline & NS & Papillary & Right upper pole & 3.4 & \\
\hline & & Clear cell & Right upper pole & 1 & \\
\hline & NS & Clear cell & Right upper pole & 5.7 & \\
\hline & & Chromophobe & Right lower pole & 1 & \\
\hline & NS & Chromophobe & Right lower pole & 12 & \\
\hline & & Papillary & Right upper pole & 4 & \\
\hline Lee et al. & $79 / M$ & Clear cell & Right mid portion & 2 & \\
\hline & & Chromophobe & Right lower pole & 3.5 & \\
\hline Quiroga- & $67 / M$ & Clear cell & Right upper pole & 4.1 & \\
\hline Garza et al. & & Tubulocystic & Right mid lateral & 2 & \\
\hline Current & $42 / M$ & Papillary & Right lower pole & 10 & Tumor-in-tumor \\
\hline $\operatorname{case}^{\star}$ & & Collecting duct & Right lower pole & 3.5 & morphology \\
\hline
\end{tabular}

${ }^{*}$ Cases with single mass, or tumor-in-tumor morphology or histologic transition. RCC - renal cell carcinoma, CRCC - chromophobe renal cell carcinoma, PRCC - papillary renal cell carcinoma, CDC - collecting duct carcinoma, NS - not stated. 
cently, the concept of cancer stem cells has become a focus of investigation in cancer biology. It is conceivable that these particular tumors may have arisen from a cancer stem cell. Consequently, combination of the masses that are thought to arise from distal and proximal tubules may be developed from a pluripotent stem cell that has capability of both proximal and distal nephron histogenesis.

Our case is unique because this is the first case of synchronous PRCC and CDC seen as a single mass. Previously reported PRCC and CDC combinations were completely separate tumors at different locations in the same kidney. In such tumors, the possibility of collision tumor should also be considered. We speculate that in a case with separate tumors located close to each other in the same kidney, the more aggressive one may invade the other and may present an image like a single mass, or "tumor-in-tumor" morphology or histologic transition. In our case, the CDC is expected to behave in an aggressive way. Infiltration and encircling of the PRCC by the CDC may form the morphology what we have described.

\section{Conflict of interest}

The authors declare no conflict of interest.

\section{References}

1. Srigley JR, Delahunt B. Uncommon and recently described renal carcinomas. Mod Pathol 2009; 22: 2-23.

2. Tokuda N, Naito S, Matsuzaki O, Nagashima Y, Ozono S, Igarashi T. Japanese Society of Renal Cancer. Collecting duct (Bellini duct) renal cell carcinoma: a nationwide survey in Japan. J Urol 2006; 176: 40-3.

3. Prasad SR, Humphrey PA, Catena JR, et al. Common and uncommon histologic subtypes of renal cell carcinoma: imaging spectrum with pathologic correlation. Radiographics 2006; 26: 1795-806.

4. Hart AP, Brown R, Lechago J, Truong LD. Collision of transitional cell carcinoma and renal cell carcinoma. An immunohistochemical study and review of the literature. Cancer 1994; 73: 154-9.

5. Jimenez RE, Eble JN, Reuter VE, et al. Concurrent angiomyolipoma and renal cell neoplasia: a study of 36 cases. Mod Pathol 2001; 14: 157-63.

6. Morelli L, Pusiol T, Piscioli I, Larosa M, Pozzoli BL, Monıca B. Concurrent occurrence of three primary neoplasms with different hystotype in the same kidney, associated with an adenoma of the omolateral adrenal gland: first case report. Int J Urol 2006; 13: 1236-9.

7. Renshaw AA, Henske EP, Loughlin KR, Shapiro C, Weinberg DS. Aggressive variants of chromophobe renal cell carcinoma. Cancer 1996; 78: 1756-61.

8. Auguet T, Molina JC, Lorenzo A, Vila J, Sirvent JJ, Richart C. Synchronus renal cell carcinoma and Bellini duct carcinoma: a case report on a rare coincidence. World J Urol 2000; 18: 449-51.

9. Daniel L, Zattara-Cannoni H, Lechevallier E, Pellissier JF. Association of a renal papillary carcinoma with a low grade tumour of the collecting ducts. J Clin Pathol 2001; 54: 637-9.
10. Gong Y, Sun X, Haines GK 3rd, Pins MR. Renal cell carcinoma, chromophobe type, with collecting duct carcinoma and sarcomatoid components. Arch Pathol Lab Med 2003; 127: 38-40.

11. Jun SY, Cho KJ, Kim CS, Ayala AG, Ro JY. Triple synchronous neoplasms in one kidney: report of a case and review of the literature. Ann Diagn Pathol 2003; 7: 374-80.

12. Cho NH, Kim S, Ha MJ, Kim HJ. Simultaneous heterogenotypic renal cell carcinoma: immunohistochemical and karyoptic analysis by comparative genomic hybridization. Urol Int 2004; 72: 344-8.

13. Lindgren V, Paner GP, Flanigan RC, Clark Jl, Campbell SC, Picken MM. Renal tumor with overlapping distal nephron morphology and karyotype. Arch Pathol Lab Med 2004; 128: 1274-8.

14. Matei DV, Rocco B, Varela R, et al. Synchronous collecting duct carcinoma and papillary renal cell carcinoma: a case report and review of the literature. Anticancer Res 2005; 25: 579-86.

15. Kawano N, Inayama $\mathrm{Y}$, Nakaigawa N, et al. Composite distal nephron-derived renal cell carcinoma with chromophobe and collecting duct carcinomatous elements. Pathol Int 2005; 55: 360-5.

16. Roehrl MH, Selig MK, Nielsen GP, Dal Cin P, Oliva E. A renal cell carcinoma with components of both chromophobe and papillary carcinoma. Virchows Arch 2007; 450: 93-101.

17. Tyritzis SI, Alexandrou PT, Migdalis V, Koritsiadis G, Anastasiou I. Synchronous chromophobe and papillary renal cell carcinoma. First report and review of the pathogenesis theories. Pathol Int 2009; 59: 193-6.

18. Tsai TH, Tang SH, Chuang FP, et al. Ipsilateral synchronous neoplasms of kidney presenting as acute pyelonephritis and bladder metastasis. Urology 2009; 73: 1163. e9-11.

19. Capaccio E, Varca V, Simonato A, Toncini C, Carmignani G, Derchi LE. Synchronous parenchymal renal tumors of different histology in the same kidney. Acta Radiol 2009; 50: 1187-92.

20. Lee TH, Kim W, Lee S, et al. Double synchronous primary renal cell carcinoma with different histotypes. Clin Nephrol 2010; 74: 164-5.

21. Quiroga-Garza G, Piña-Oviedo S, Cuevas-Ocampo K, et al. Synchronous clear cell renal cell carcinoma and tubulocystic carcinoma: genetic evidence of independent ontogenesis and implications of chromosomal imbalances in tumor progression. Diagn Pathol 2012; 7: 21. 